\title{
DEVELOPMENT OF THE HIGH-PERFORMANCE WORK SYSTEMS SCALE FOR HOSPITALS: VALIDITY AND RELIABILITY STUDY
}

\author{
DOI: 10.17261/Pressacademia.2020.1276 \\ RJBM- V.7-ISS.3-2020(1)-p.128-138
}

\author{
Aysun Danayiyen ${ }^{1}$, S. Burak Bekaroglu² \\ ${ }^{1}$ Istanbul Okan University, Faculty of Health Sciences, Department of Health Management, 34959, Istanbul, Turkey. \\ aysun.danayiyen@okan.edu.tr, ORCID: 0000-0002-4782-5697 \\ ${ }^{2}$ Marmara University, Faculty of Health Sciences, Department of Health Management, 34854, Istanbul, Turkey. \\ bbekaroglu@marmara.edu.tr, ORCID: 0000-0002-0799-367X
}

Date Received: June 21, 2020

Date Accepted: September 2, 2020

To cite this document

Danayiyen, A., Bekaroglu, S. B., (2020). Development of the high-performance work systems scale for hospitals: validity and reliability study. Research Journal of Business and Management (RJBM), Vol.7(3), p.128-138.

Permanent link to this document: http://doi.org/10.17261/Pressacademia.2020.1276

Copyright: Published by PressAcademia and limited licensed re-use rights only.

\section{ABSTRACT}

Purpose- This study aims to develop a scale that evaluates the level of HPWS practices in hospitals based on employee perceptions and to make its validity and reliability.

Methodology- The study was conducted via an online survey in three public education and research hospitals. The sample consisted of 309 clinical and administrative employees. After performed face and content validity, a pilot study conducted. The item-total score correlations and Cronbach's alpha coefficients were calculated. Construct validity was tested. Correlation analysis was performed to test scale-related validity. Findings- Overall, a 29 items scale were obtained, encompassing 6 factors that explained 78\% of the total variance. Reliability coefficients varied between .96 and .87 . Confirmatory factor analyses were found to show good fit. Evidence for criterion-related validity was obtained after correlation analysis.

Conclusion- The scale that proven content, construct, and predictive validity, can be used to evaluate the level of high-performance work systems in hospitals.

Keywords: High-performance work systems, human resources management, healthcare, health workforce, validity, and reliability. JEL Codes: M50, J45, 119

\section{INTRODUCTION}

High Performance Work Systems (HPWSs) was first called high-involvement management by Lawler in 1986 (Ross \& Koys, 2011 ). In 1994, it was proposed as a model that increases the commitment of employees who independently use their discretion to fulfill their professional requirements in accordance with organizational goals (Arthur, 1994). In 1995, Huselid made the widely accepted HPWS definition "a set of innovative human resources (HR) practices aimed at improving organizational performance through employees" (Huselid, 1995).

Studies have been conducted on the basis of the systems approach by important researchers such as Delery and Doty (1996), Becker and Gerhart (1996), Pfeffer (1995) and particularly Huselid (1995). Key empirical evidence of these studies has demonstrated that HPWSs improve employee skills and promote active involvement in, and commitment to, workplace activities, thereby encouraging organizational growth and effectiveness. Based on the research conducted, the concept of HPWS has been defined in the literature as a body of HR practices designed to ensure employee identification with overall objectives and to increase employee engagement and involvement in order to deliver superior and sustainable performance by an organization when compared to its rivals. It is called "high performance" because it is designed to deliver to the organization superior and sustainable performance, and it combines a number of HR practices, which strengthen each other, to enhance organizational efficiency and effectiveness in a way that creates synergistic effects. The effectiveness of HPWS and its contribution to performance were first investigated in the manufacturing sector and then in the service sector. Most of the studies in the service 
sector are in organizations such as restaurants, banking, and hospitality sector, but a growing number of studies are being conducted in healthcare services around the world.

In the remainder of this article, we review theoretical work suggesting that HPWSs can be the underused strategy to improve the quality of care and patient safety, especially when its components have high internal and external fit. Next, focused specifically on addressing the significance of the findings, the study adhered to the literature in terms of dimensions and could contribute to the literature with a comprehensive measurement of HPWS in the hospital. Finally, we compare the results of this study with some of the key policy and research results of studies on scale development.

\section{LITERATURE REVIEW}

Health is a labor-intensive service area that requires effective HR management practices. Research in healthcare services demonstrated that HPWSs affect employee engagement (Mihail \& V. Kloutsiniotis, 2016), satisfaction (Spence Laschinger, Finegan, Shamian, \& Wilk, 2001), behavior and attitudes (Harley, Allen, \& Sargent, 2007), patient outcomes such as patient safety grade (Etchegaray \& Thomas, 2015), mortality rate (West et al., 2002), and patient satisfaction. In addition, researchers found that HPWSs are negatively related to burnout and reduce the intention to quit the job (Ang, Bartram, McNeil, Leggat, \& Stanton, 2013). Previous studies emphasized that the use of evidence-based management practices (also known as HPWSs) such as training, development, participation in decision-making, and performance appraisal is an important and underused strategy to improve the quality of care and patient safety (McAlearney et al., 2011). For this underutilized strategy to become widespread in healthcare, health managers need to share more application examples and research results on HPWS, which is evidence-based management practices. Despite the increase in HPWS research in healthcare, there is a need for experimental studies in the health system where the clinical and patient safety results of high-performance work systems and its reflection on healthcare professionals can be discussed and measured. In addition to examining the studies mentioned above, recent studies have given the following results, especially in terms of the scales they use.

McAlearney, Hefner, Robbins, and Garman (2016) explored the potential role HPWS could play in explaining the differences in infection rate reduction efforts in hospitals that are following a program implemented in 8 hospitals in the US in 2016. Data have been collected through in-depth interviews with 194 managers from these hospitals. There was evidence from hospitals that participate and successful in infection reduction programs and facilitated the adoption and consistent implementation of the HPWS model, but applications of this HPWS model are almost negligible in hospitals with low performance. Model of HPWS subsystem (bundle) consists of 14 management practices under the sub-dimensions: (a) employee engagement, (b) appropriate leadership, (c) skill acquisition and development, and (d) empowering employees. The HPWS model should be presented on an evidence-based basis as a regulatory framework that can be applied to facilitate quality and patient safety efforts in healthcare (McAlearney, Hefner, Robbins, \& Garman, 2016). This study contains a qualitative feature to assess HPWS and reflects the executive perspective.

In a study conducted by Kellner, Townsend, and Wilkinson in 2017, many non-profit organizations (foundations) show that the performance goals of HPWS practices will not conflict with a "values-based approach" to manage people. In the article, 83 human resources managers from foundation hospitals in Australia were asked how these two approaches could coexist and how they could result in a "strong HRM system" and climate with qualitative research techniques. Despite some contradictions that interviewees call "the balance between mission and margin", careful alignment of corporate value focuses on HPWS has resulted in a stronger climate, positive employee results, and a high-performance HRM system. The article is important for HPWS to develop an understanding of how it can contribute to the performance of nonprofits, and specifically addresses the call for research on value-based HPWS practices (Kellner, Townsend, \& Wilkinson, 2017). This study contains a qualitative feature to measure HPWS that is the human resources managers' perspective.

In 2017, Kloutsiniotis and Mihail reported the effects of employees' emotional engagement on their intention to leave, in a sample of 119 nurses and health workers and 117 doctors from 7 hospitals in Greece. HPWS has been measured in terms of training, participation in decisions, employment security, performance evaluation, job determination, and employee autonomy. Overall, 31 items were used, encompassing seven sub-scales. It is understood that HPWS practices affect the participation and job satisfaction of the employees, which leads to an increase in commitment and a decrease in the intention to leave. Although this result, which is different from the literature, cannot be generalized due to the effects of the financial crisis in Greece. It is a study that should be supported by such researches claiming that HPWS can be an efficient and effective approach even in turbulent times (Kloutsiniotis \& Mihail, 2017). This study contains a quantitative feature to measure HPWS and uses the most common scales mix in the area developed by Ang et al., (2013) and Zacharatos, Barling, and Iverson (2005). Overall, 31 items were used, encompassing seven sub-scales. 
In 2018, Robbins \& McAlearney explored how the implementation of HPWS in hospitals in the USA could facilitate or remove barriers to employees talking about problems by interviewing 67 executive participants from 5 hospitals. Research findings showed that talking about problems was considered an important factor influencing quality improvement and/or patient safety initiatives across all five organizations. Management efforts to facilitate conversation include both direct practices such as using structured communication processes and reporting systems, and complementary practices that support speaking. Both direct and complementary practices show that HPWS is used to encourage employees to speak by harmonizing them with leadership, talent acquisition and development, and employee empowerment practices. Both conceptual and qualitative evidence supporting the applicability of HPWS as a management model to systematically facilitate speech in health institutions is presented in this study. The application of an evidence-based framework provides examples of specific management practices that enable an organizational perspective rather than an employee perspective to be taken into account and has been successfully implemented to facilitate conversation (Robbins \& McAlearney, 2018). This research contains increasing evidence to support the applicability of HPWS as a valuable strategy for influencing quality and safety in healthcare organizations but reflects the executive perspective.

Gkorezis, Georgiou, and Theodorou (2018) examined the mediation mechanism of organizational cynicism in the relationship between high-performance work practices and intention to leave with the participation of 299 nurses from private hospitals in Cyprus in 2018. HPWS was measured as a single factor with 11 questions from the areas of recruitment and selection, training and development, evaluation, awards, and job security. They found that organizational cynicism mediates the relationship between high-performance work practices and intention to quit and that this indirect effect is dependent on the educational background of nurses which was a dimension of human resource management (Gkorezis, Georgiou, \& Theodorou, 2018).

Mielke et al., (2019) conducted a study with 281 healthcare professionals from a hospital in Switzerland. They used the 10-item HPWS scale, previously developed by Etchegaray and Thomas (2015) to ensure its cultural validity and reliability. HPWS was significantly associated with the security and teamwork climate. In clinical practice, it was stated that the HPWS scale fits the model very well with its 9-item structure and can be used for in-hospital and inter-hospital comparison. However, the scale has only one dimension and requires some adaptation to express and re-evaluate psychometric properties in other clinical areas (Mielke et al., 2019).

Wang, Xing, and Zhang (2019) investigated the dark side of HPWS in the health sector in a study conducted with 80 physicians, 125 nurses, and 18 other healthcare personnel from a hospital in China in 2019. In previous studies, there were results from other sectors that HPWS increased the level of burnout and workload. To measure HPWS in health services, the 24-item scale was used. This scale includes six HR practices for service quality with those dimensions: selection, training, performance management, reward, participation and teamwork, and information sharing, but the scale was originally tailored to the tourism industry by Hong, Jiang, Liao, and Sturman (2017).

When reviewing the literature, it has been seen that most of the studies were conducted in private health institutions in the USA, Australia, China, Switzerland, Greece, England, South Korea, and Cyprus. In Turkey, HPWSs have been studied in various sectors such as the banking and defense industries. However, no such study regarding HPWSs was identified in the healthcare sector even though the theory of HPWSs has been adopted even by public hospitals in recent years to ensure effective and efficient management of high-quality health workforce through a transformation program in the health sector. In the literature, it is emphasized that HRM in the service sector is different from the HRM in the manufacturing sector, that public sector HRM is different from private-sector practices (Lengnick-Hall, Lengnick-Hall, Andrade, \& Drake, 2009), that the differences in HRM at different life cycle stages should continue to be examined, and more empirical evidence is needed from public health institutions. In this regard, the literature highlights the need for a multifaceted measurement of the HPWSs enabled by both private and especially public healthcare providers and a discussion on the associated results.

Furthermore, a review of the literature revealed that the extent to which an organization implements the HR aspects were measured by scales answered by managers (e.g., Etchegaray \& Thomas, 2011), from their perspective during HPWS measurement. Studies on HPWSs often ignore employee experience of HPWS (Van De Voorde, Paauwe, \& Van Veldhoven, 2010). A balanced perspective is needed because employees are the ones who implement high-performance applications and create high performance, especially in the service sector. Moreover, asking employees about the level of HPWSs will better reflect the intensity of practices and the way such practices are perceived. Therefore, it was believed that there is a need to develop a scale, which includes both the HPWS dimensions that are widely accepted in the literature (Garman, McAlearney, Harrison, Song, \& McHugh, 2011; Posthuma, Campion, Masimova, \& Campion, 2013) and the HR practices utilized by the hospitals, as well as allowing assessments of employee perceptions of HPWSs. 
In this context, the aim of this study is to develop a scale that assesses the level of HPWS practices in hospitals based on employee perception and to establish the validity and reliability of such a scale.

\section{DATA AND METHODOLOGY}

This methodological study was conducted to develop a Turkish HPWS scale and to test the validity and reliability of the scale in order to measure the level of high-performance work practices implemented by hospitals. The ethics committee approval was obtained from the Ethics Committee of Marmara University Institute of Health Sciences (No: 14.01.2019-07).

The scope of the study covers employees of the top ten training and research hospitals in Turkey according to the Public Hospitals Statistical Report 2017 by the General Directorate of Public Hospitals based on the variety of branches, bed capacity, and the number of staff and applicants. Upon the consent of three hospitals located in Istanbul, Malatya, and Bursa, the study was conducted in these three training and research hospitals between September 2019 and December 2019. Employees were contacted by an online survey through hospital managers. In total, 324 out of 4307 employees who were delivered questionnaires turned in a response. The survey response rate was 7.5\%. Becker and Huselid (1998) indicated that the response rate of studies on HPWSs ranged from $6 \%$ to $28 \%$ with an average of $17.4 \%$. After questionnaires with missing or faulty data were eliminated, 309 forms were evaluated.

The questionnaire comprises three parts. The first part comprises items about demographic characteristics of participants, while the second part included items from the Structural Empowerment Scale developed by Laschinger et al.(Spence Laschinger et al., 2001) and items from the Psychological Empowerment scale developed by Spreitzer (1995). Turkish adaptation of the scales was carried out by Sürgevil, Tolay, and Topoyan (2013).

The third part consisted of a 32-item "Draft High-Performance Work Systems Scale" developed by researchers. In the first stage of developing the draft questionnaire, an item pool was created with questions of participation in decision-making, employment security, training and development, compensation, transformational leadership, performance appraisal (Mayer \& Davis, 1999), and equal employment opportunity (Ang et al., 2013). This was done by drawing upon the two main scales commonly used in the field (Villajos, Tordera, \& Peiró, 2018; Zacharatos et al., 2005). The back translation (Brislin, 1986) method for the translation of scale items was applied with assistance from the Department of Foreign Languages of Istanbul Okan University. A face validity study was conducted by conferring with healthcare personnel; a content validity study was conducted in accordance with expert opinions. A draft scale of 32 items was obtained after the analyses made in preliminary trial/pilot study with 157 participants.

The reliability of the 32-item draft scale that was administered to the main sample was tested using the item-total correlation and Cronbach's alpha coefficient. Principal components analysis and the Varimax rotation technique were used for the explanatory factor analysis to test the construct validity. A confirmatory factor analysis was made to test whether the data fit the model. Finally, a criterion-related validity analysis was performed to test the effectiveness of the scale. All data analyses were made using the IBM SPSS 24 and IBM SPSS AMOS 24 programs.

\section{FINDINGS}

\subsection{Face and Content Validity}

The item pool created through a literature review was conferred with five experts, four of whom were experienced in healthcare sector and held a doctoral degree and one who was from the business management field. Experts rated each of items using four options as "item is not appropriate," "item should be seriously reviewed," "item should be slightly reviewed," and "appropriate." The "content validity index" was obtained by using a statistical method, the Davis technique (Davis, 1992). The content validity index was calculated by dividing the number of experts who marked the "item should be slightly reviewed" and "appropriate" options by the total number of experts. The Content Validity Index (CVI) of the 41-item draft scale was found to be .86.

In addition, the expert group was asked to rate each statement from 1 (Incomprehensible) to 4 (Comprehensible) and to clearly write down their opinions and suggestions for each statement. In accordance with the opinions of healthcare personnel and experts, changes were made in some statements. The statement, "Whether I will get a raise depends on my performance," was changed to "The share I will receive from the revolving fund depends on my performance." The statement, "If you are one of the better performers in this organization, you get one of the better raises," was changed to "If you perform better, you get one of the best shares from the revolving fund."

A pilot study is recommended after content validity in methodological studies (Erkuş, 2019). The preliminary trial/pilot application of the scale is presented below. 


\subsection{Preliminary Trial - Pilot Study}

A preliminary trial/pilot application was performed with 157 participants selected from the target population in order to obtain the scale that would be administered to the main sample. The aim of the preliminary trial is to identify potential problems in the questionnaire, to obtain preliminary reliability results related to the new scale, to detect any faults or issues with the scale, and to establish whether the new construct differs from other related structures (Slavec \& Drnovsek, 2013). This stage consists of determining the readability and comprehensibility of items, spelling errors, and the average response time.

The consistency of the scale was calculated using the Cronbach's alpha reliability coefficient in the pilot study. The Cronbach's alpha coefficient, which indicates the consistency of 41 items with the overall test, was found to be .944 . An item-total correlation value of $<.30$ indicates that the corresponding items do not correlate with the overall scale, and the internal consistency changes when such items are removed from the scale. Thus, four items with a value of <.22 were removed from the scale. (IG4R: I'm not sure how long I will be employed in my organization; P4R: Whether or not my supervisor likes me is important for my performance review; EI4R: Individual differences prevent creating equal employment opportunities in this organization; and U2: I get an average salary for this job.)

In the pilot study, the explanatory factor analysis was performed using the principal components analysis and the Varimax rotation technique. It was decided to remove the items with a factor loading of <.30, which were El1: My organization supports employees in balancing work and family responsibilities; EI2: Men and women have the same employment opportunities in this organization; and P1: The assessment of skills I have is quite error-free. After repeated analyses, factors with an eigenvalue of $\geq 1$ were obtained. The Cronbach's alpha coefficients were calculated for the reliability of the six subfactors obtained. After internal consistency tests for the dimensions, the removal of certain items (KE4R: I do not have much word on the decisions made in my workplace and KE5: I feel like I' $m$ in control of things that is going around me in my workplace) was observed to increase the reliability, and therefore, these two items were removed from the scale. The sample adequacy of the tests was analyzed using the Kaiser-Meyer-Olkin $(\mathrm{KMO})$ value and Bartlett's test of sphericity (KMO $=.903$, Bartlett's test of sphericity $\left.\chi^{2}=3371.34, \mathrm{df}=496, \mathrm{p}<.001\right)$. The draft HPWS scale was finalized with 32 items in six subfactors (Danayiyen \& Bekaroglu, 2019).

It was established that the draft scale, which was reduced to 32 items after the analyses performed in the preliminary trial, was completed in an average of 13 minutes. The next procedure to be conducted was the administration of the draft scale to the main sample.

\subsection{Descriptive Statistical Findings}

The main sample consists of a total of 309 participants. Among the study participants, $72.2 \%(n=223)$ were female and $27.8 \%(n$ $=86$ ) were male. The age range of participants varied between 19 and 65 years, and the mean age was approximately 33.9 years. In addition, $61.2 \%(n=189)$ of the participants had bachelors and higher levels of education. The mean work experience of employees was 11.3 years, the mean years of seniority in their organization was 7.1 years, and the mean weekly working hours were 46.4 hours. A great majority $(n=298,96.4 \%)$ of the participants were working during daytime and in mixed shifts. Of the employees, $35.3 \%(n=109)$ were working in administrative, $64.7 \%(n=200)$ were working in clinical units, and $84.8 \%(n=262)$ were in direct contact with patients. Regarding the professions of participants, $47.3 \%(n=146)$ were nurses, midwives, or medical assistants; $30.4 \%(n=94)$ were medical secretaries or data entry specialists; $12.3 \%(n=38)$ were physicians; $6.1 \%(n=19)$ were technical experts or technicians; and 3.9\% $(n=12)$ were managers or coordinators. Finally, a great majority $(n=216,69.9 \%)$ of the participants were members of a union.

\subsection{Construct Validity}

Explanatory factor analyses were performed using PCA and the Varimax rotation technique. Sample adequacy of the analyses was analyzed using the Kaiser-Meyer-Olkin (KMO) value and Bartlett's test of sphericity (KMO $=.940$, Bartlett's test of sphericity $\chi^{2}=$ $8967.30, \mathrm{df}=406, \mathrm{p}<.001$ ). Table 1 presents the dimensions from the factor analysis explained variance, eigenvalues, and means. The explanatory power of the scale was 78\%, while Cronbach's alpha was .96.

The Cronbach's alpha coefficients for the dimensions were calculated and found to vary from .96 to .87. Based on the internal consistency tests of the dimensions, it was decided to remove the following three items from the scale to increase the validity and reliability of the scale: E2: The organization I work for will remunerate me if I receive further training, El3: Training and awareness activities are carried out in this organization in order to create equal employment opportunities, El5: Managers care about providing equal employment opportunities in this organization. 
The number of scale items was reduced to 29 upon the removal of these three items. The six subdimensions from the factor analysis were named according to the items loading on the corresponding factors (Karagöz, 2019; Şencan, 2005).The six dimensions from the factor analysis were named as follows: performance appraisal, transformational leadership, compensation, employment security, training and development, participation in decision-making and teamwork. These are taken place in Table 1 and briefly described after the table.

Table 1: Variances Explained, Reliabilities and Factor Loadings of HPWS Scale

\begin{tabular}{|c|c|c|c|c|c|c|}
\hline 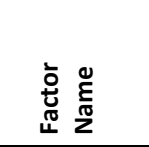 & Items & 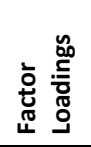 & 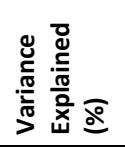 & 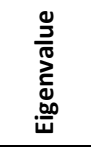 & 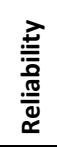 & 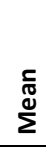 \\
\hline \multirow{6}{*}{ 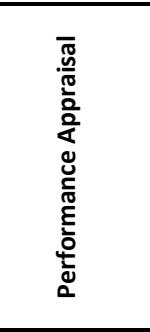 } & P6: How many "extra" things I do is important to my performance review & .839 & \multirow{6}{*}{15.91} & \multirow{6}{*}{14.53} & \multirow{6}{*}{.94} & \multirow{6}{*}{2.9} \\
\hline & P5: How much effort I put into my job is important to my performance review & .833 & & & & \\
\hline & $\begin{array}{l}\text { P3: How many mistakes I make in my work is important to my performance } \\
\text { review }\end{array}$ & .812 & & & & \\
\hline & P2: How much work I get done is important to my performance review & .789 & & & & \\
\hline & $\begin{array}{l}\text { P8: Coming up with good ideas for the company improves my performance } \\
\text { review }\end{array}$ & .667 & & & & \\
\hline & $\begin{array}{l}\text { P7: Finding ways for the company to save money is important to my } \\
\text { performance review }\end{array}$ & .562 & & & & \\
\hline \multirow{5}{*}{ 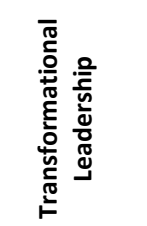 } & LD2: My supervisor encourages me to express my ideas and opinions. & .791 & \multirow{5}{*}{15.86} & \multirow{5}{*}{2.56} & \multirow{5}{*}{.96} & \multirow{5}{*}{2.9} \\
\hline & LD3: My supervisor gets me to look at problems from many different angles & .790 & & & & \\
\hline & LD4: My supervisor listens attentively to my concerns & .771 & & & & \\
\hline & $\begin{array}{l}\text { LD5: My supervisor treats each of us as individuals with different needs. } \\
\text { abilities. and aspirations }\end{array}$ & .753 & & & & \\
\hline & LD1: My supervisor talks enthusiastically about what needs to be accomplished & .742 & & & & \\
\hline \multirow{6}{*}{ 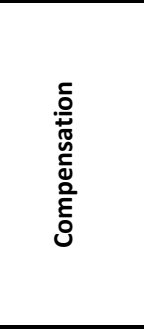 } & $\begin{array}{l}\text { P9: The share I will receive from the revolving fund depends on my } \\
\text { performance }\end{array}$ & .791 & \multirow{6}{*}{13.02} & \multirow{6}{*}{1.89} & \multirow{6}{*}{.87} & \multirow{6}{*}{2.1} \\
\hline & $\begin{array}{l}\text { P10: If you perform better, you get one of the best shares from the revolving } \\
\text { fund }\end{array}$ & .780 & & & & \\
\hline & U3:There is an equitable compensation system here & .705 & & & & \\
\hline & U1: I get a competitive salary on the healthcare job market & .683 & & & & \\
\hline & P11: If I perform well. my chances of moving up are improved & .615 & & & & \\
\hline & $\begin{array}{l}\text { U4: Working in this organization has additional attractive benefits (flexible } \\
\text { working hours. the number of days off. etc.) }\end{array}$ & .598 & & & & \\
\hline \multirow{4}{*}{ 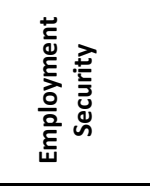 } & IG2: My job is guaranteed in where I work & .865 & \multirow{4}{*}{12.80} & \multirow{4}{*}{1.46} & \multirow{4}{*}{.93} & \multirow{4}{*}{3.5} \\
\hline & IG1: This organization provides me with retirement security & .844 & & & & \\
\hline & IG5: My work contract that offers job security & .840 & & & & \\
\hline & $\begin{array}{l}\text { IG3: The guarantee of being employed in my organization as long as I do good } \\
\text { work }\end{array}$ & .787 & & & & \\
\hline \multirow{5}{*}{ 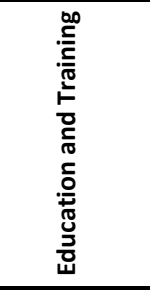 } & $\begin{array}{l}\text { E4: The opportunity to develop new skills and knowledge for my current job. } \\
\text { or for possible future positions }\end{array}$ & .761 & \multirow{5}{*}{12.80} & \multirow{5}{*}{1.12} & \multirow{5}{*}{.92} & \multirow{5}{*}{3.0} \\
\hline & E3: The opportunity to receive training and attend courses and workshops & .751 & & & & \\
\hline & E5: Support in planning my professional development & .723 & & & & \\
\hline & $\begin{array}{l}\text { E1: The opportunity to receive enough training for me to learn new ways to do } \\
\text { my job }\end{array}$ & .675 & & & & \\
\hline & $\begin{array}{l}\text { E6: The opportunity to receive training above the legal obligation for both } \\
\text { patient and employee safety }\end{array}$ & .654 & & & & \\
\hline \multirow{4}{*}{ 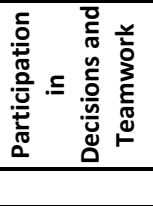 } & KE2: If there is a decision to be made. everyone is involved in it. & .765 & \multirow{3}{*}{7.59} & \multirow{3}{*}{1.05} & \multirow{3}{*}{.90} & \multirow{3}{*}{3.0} \\
\hline & KE1: I feel I am really part of my work group & .681 & & & & \\
\hline & KE3: My organization places a great deal of importance on team development & .623 & & & & \\
\hline & & Total $=$ & 77.99 & & .96 & 2.9 \\
\hline
\end{tabular}


F1: The performance appraisal dimension consists of six items. This dimension covers the importance placed by the hospital on performance appraisal by scoring or proportioning sensitivity to new ideas, extra contribution during business processes, finding ways of saving, and doing error-free work.

F2: The transformational leadership dimension consists of five items. Transformational leaderships refer to encouraging followers to discover new and innovative ways over and above solving their problems, accepting individual differences of employees, and regarding the needs and abilities of each individual when giving assignments.

F3: The compensation dimension consists of six items. It covers a fair and competitive compensation of labor and the trust in the consistency of the measuring instrument utilized by organizations to pay from the revolving funds alongside the benefits.

F4: The employment security dimension consists of four items. Employment security, which is a traditional form of assurance that can be defined as a long-term perspective provided by a working system, refers to the perceived risk of job loss in the near future, and thereby, it is an important determinant for job satisfaction and high performance.

F5: The training and development dimension consists of five items. It is one of the most important distinctive features of a highperformance working system, covering the creation of opportunities required for active participation; information acquisition; transformation into skills and implementation; planning for training on legal obligations; and encouraging employee development.

F6: Participation in decision-making and teamwork consist of three items. This dimension measures the importance placed by the hospital on teamwork; the participation of individuals in decision-making; and the question of whether individuals perceive themselves as part of the team. It delivers the message that the opinions of employees and primarily themselves are valued.

The construct finalized in accordance with the explanatory factor analysis was verified through a confirmatory factor analysis, which evaluates the extent to which a factorial model comprising latent variables constituted by several observable variables fit the actual data (Jöreskog \& Sörbom, 1984; Karagöz, 2019). A confirmatory factor analysis was performed to verify the latent construct obtained and to determine the fit indices. The results of the first analysis produced warnings for modification, indicating that there was covariance between fit indices and certain standard errors.

The results of analysis after the modification revealed positive improvements in the fit indices. Table 2 shows that each observed item was statistically significantly predicted by the associated latent dimension when evaluating the model fit statistics of the firstorder confirmatory analysis.

Table 2: Goodness-of-Fit Statistics for CFA Models*

\begin{tabular}{lrrrrrrr}
\hline Model & $\chi^{2}$ & df & $\begin{array}{r}\chi^{2} / \mathbf{d f} \\
(\leq 5)\end{array}$ & $\begin{array}{r}\text { CFI } \\
(\geq .95)\end{array}$ & $\begin{array}{r}\text { GFI } \\
(\geq .90)\end{array}$ & $\begin{array}{r}\text { RMSEA } \\
(\leq .08)\end{array}$ & $\begin{array}{r}\text { PCLOSE } \\
(>.050)\end{array}$ \\
\hline First-Order CFA & 573.07 & 342 & 1.67 & .97 & .89 & .04 & .778 \\
Second-Order CFA & 575.59 & 349 & 1.64 & .97 & .89 & .04 & .842 \\
\hline
\end{tabular}

*Norm values are in parentheses.

The most commonly used fit indices are reported (Cole, 1987; Karagöz, 2019) to be Chi-Square Goodness of fit ( $\chi^{2}$ ), Root Mean Square Error of Approximation (RMSEA), Comparative Fit Index (CFI), and Goodness of Fit Index (GFI). Because of GFI values can be overly influenced by sample size, values greater than or equal to .85 are also considered within acceptable limits of fit (Byrne, 2010). Upon examining the coefficients indicating the relationship between the observed variables and the factors of the factorial model of the developed scale, it was concluded that all coefficients were at a good level. It was ascertained from the model fit statistics of the second-order confirmatory factor analysis that the data fit the model well.

\subsection{Criterion-Related Validity}

Criterion-related validity is used to measure how well one measure estimates the outcome of another measure in order to determine the effectiveness of the instrument. If a test is useful to predict a past, present, or future performance or behavior, then it has this type of validity (Gürsakal, 2001). Criterion-related validity is divided into two subgroups. Predictive validity is obtained by calculating the correlation between the predictive score obtained from the scale and the criterion known to measure the properties intended to be measured (Cook \& Beckman, 2006). A simultaneous application is conducted for Concurrent validity. The developed scale is administered simultaneously with another scale that examines the same or an associated construct and was previously proven to be valid (Mielke et al., 2019). This analysis was used to examine the associations between the subdimensions of the HPWS scale and the empowerment scale, with the latter chosen because various relationships of these two scales have been discussed in previous studies (Laschinger, Finegan, Shamian, \& Wilk, 2004; Spence Laschinger et al., 2001). 
Table 3: Results of Bivariate Correlation Analysis for Concurrent Validity

\begin{tabular}{|c|c|c|c|c|c|c|c|c|c|}
\hline Variables & M & SD & 1 & 2 & 3 & 4 & 5 & 6 & 7 \\
\hline 1. Performance appraisal & 2.94 & 1.13 & & & & & & & \\
\hline 2. Transformational leadership & 2.92 & 1.20 & $.611^{* * *}$ & & & & & & \\
\hline 3. Compensation & 2.11 & .97 & $.643^{* * *}$ & $.521^{* * *}$ & & & & & \\
\hline 4. Employment security & 3.54 & 1.08 & $.503^{* * *}$ & $.526^{* * *}$ & $.362^{* * *}$ & & & & \\
\hline 5. Training and development & 3.01 & 1.08 & $.637^{* * *}$ & $.712^{* * *}$ & $.546^{* * *}$ & $.591^{* * *}$ & & & \\
\hline $\begin{array}{l}\text { 6. Participation in decision making and } \\
\text { teamwork }\end{array}$ & 3.00 & 1.12 & $.566^{* * *}$ & $.674^{* * *}$ & $.475^{* * *}$ & $.531^{* * *}$ & $.652^{* * *}$ & & \\
\hline 7. Structural empowerment & 3.04 & 1.00 & $.597^{* * *}$ & $.661^{* * *}$ & $.486^{* * *}$ & $.540^{* * *}$ & $.698^{* * *}$ & $.546^{* * *}$ & \\
\hline 8. Psychological empowerment & 3.86 & .85 & $.411^{* * *}$ & $.398^{* * *}$ & $.257^{* * *}$ & $.479^{* * *}$ & $.414^{* * *}$ & $.471^{* * *}$ & $.603^{* * *}$ \\
\hline
\end{tabular}

$\mathrm{N}=309 ; \mathrm{M}:$ mean; SD: standard deviation.

(1-6) belong to HPWS scale; (7-8) belong to Empowerment scale.

$* * * \mathrm{p}<.001$.

The correlation analysis revealed significantly positive correlations between the structural empowerment dimension of the empowerment scale and the HPWS scale dimensions: performance appraisal $(r=.597, p<.001)$, transformational leadership ( $r=$ $.661, p<.001)$, compensation $(r=.486, p<.001)$, employment security $(r=.540, p<.001)$, training and development $(r=.698, p$ $<.001)$, and participation in decision-making and teamwork $(r=.546, p<.001)$. As shown in Table 3 , there were also significantly positive correlations between the psychological empowerment dimension and performance appraisal $(r=.411, p<.001)$; transformational leadership $(r=.398, p<.001)$; compensation $(r=.257, p<.001)$; employment security $(r=.479, p<.001)$; training and development $(r=.414, p<.001)$; and participation in decision-making and teamwork $(r=.471, p<.001)$. These findings constitute evidence for the criterion-related validity of the scale and take place in Table 3.

\section{DISCUSSION AND CONCLUSION}

First, the literature was reviewed, and an item pool of the scale was created by drawing from the two scales commonly used in the field and adding two different dimensions. After content validity and face validity were achieved through the opinions of five experts with experience in the healthcare sector and a doctoral degree, a pilot study was conducted to test the items on 157 individuals representing the main sample. Upon the removal of a total of nine items, the draft scale was finalized with 32 items and six factors.

The draft scale was then administered to the main sample of 309 individuals. The literature includes different views on the sample size in scale development studies. There are opinions arguing that a sample size of 5 to 10 times of the number of items is enough (Cohen \& Swerdlik, 2018; Şencan, 2005), whereas some researchers suggest that 50 is too weak, 100 is weak, 200 is moderate, 300 is good, 500 is very good and 1000 is perfect for an adequate sample size (Comrey, 2013). The sample size of the present study is considered good in both views as well as being adequate according to the Kaiser-Meyer-Olkin (KMO) value and Bartlett's test of sphericity.

Construct validity analyses were carried out by administering the draft scale to the main sample. The present study primarily used the combination of explanatory factor analysis and confirmatory factor analysis, which is a technique used for construct analysis in psychological, sociological, educational, political sciences, marketing, etc. studies (Karagöz, 2019). After the explanatory factor analysis, a further three items were removed from the draft scale. The equal employment opportunities dimension, which was projected during scale development, could not be obtained from the analysis upon the removal of these items. It would be appropriate if the equal employment opportunities dimension was described as providing equal job opportunities for better understanding rather than defining it as the affirming and proactive use of differences to achieve high performance beyond legal obligations. However, it is common to change dimensions during scale development after statistical analyses (Parasuraman, Zeithaml, \& Berry, 1988).

Various methods are used to name the subdimensions in the literature. One of these is naming by considering the common characteristics of the items loading on subdimensions. Another is naming by referring to the item with the highest loading value among the items loading on the subdimension (Karagöz, 2019; Şencan, 2005). The former method was chosen in this study, and the scale was finalized with 29 items comprising the performance appraisal, transformational leadership, compensation, 
participation in decision-making and teamwork, training and development, and employment security dimensions. The naming of the factors was made considering scales developed in various fields of the literature, studies on the subject, and recommendations of expert opinions (Ang et al., 2013; Etchegaray, St. John, \& Thomas, 2011; Özçelik, Aybas, \& Uyargil, 2016; Villajos et al., 2018; Zacharatos et al., 2005). Upon examining the coefficients indicating the relationship between the observed variables and the factors of the factorial model of the developed scale, it was concluded that all coefficients were at a good level. It is believed that the study adhered to the literature in terms of dimensions and will contribute to the literature because there is no previous study performed in this context.

The reliability of the scale was established by calculating the Cronbach's alpha reliability coefficient. Such coefficients were considered individually for each subdimension. The Cronbach's alpha reliability coefficients for the six subdimensions varied from .87 to .96 , and the Cronbach's alpha coefficient was .96 for the overall scale.

Finally, an analysis of the criterion-related validity was performed for the effectiveness of the instrument. This analysis examined the associations between the subdimensions of the HPWS scale and the empowerment scale. The empowerment scale was chosen for the analysis because previous studies (Laschinger et al., 2004; Spence Laschinger et al., 2001) have discussed that HPWS practices drive personnel to improve their performance, thereby leading the institution to achieve high performance, and have demonstrated empowerment as a mediator. The results of the correlation analysis indicated moderately positive correlations between the dimensions of the two scales, which prove how well the scale effectively predicted the outcome of another measurement.

Considering the findings presented, it has been concluded that the scale that proven content, construct, and predictive validity, can be used to evaluate the level of high-performance work systems in hospitals. The HPWS scale can be recommended for future research to examine complicated relationships, such as the impact of human resource management on organizational performance, quality of service, clinical outcomes, and a public health issue like patient safety in hospitals.

The limitations of the research were that the study population consisted of personnel from three hospitals because of the difficulties in obtaining research permits from public hospitals and that the validity of the scale over time could not be verified because of the intensive workload of the healthcare personnel. Regarding this, the scale can be used again and tested for consistency over time in different sample groups.

\section{REFERENCES}

Ang, S. H., Bartram, T., McNeil, N., Leggat, S. G., \& Stanton, P. (2013). The effects of high-performance work systems on hospital employees' work attitudes and intention to leave: a multi-level and occupational group analysis. International Journal of Human Resource Management, 24(16), 3086-3114. https://doi.org/10.1080/09585192.2013.775029

Arthur, J. B. (1994). Effects of human resource systems on manufacturing performance and turnover. Academy of Management Journal, 37(3), 670-687. https://doi.org/10.5465/256705

Becker, B. E., \& Huselid, M. A. (1998). High performance work systems and firm performance: a synthesis of research and managerial implications. Research in Personnel and Human Resource Management, 53-102. https://doi.org/10.1021/jp001392z

Becker, B., \& Gerhart, B. (1996). The impact of human resource management on organizational performance: progress and prospects. Academy of Management Journal, 39(4), 779-801. Retrieved from http://www.jstor.org/stable/256712

Brislin, R. W. (1986). The wording and translation of research instruments. In: Lonner, W. J., \& Berry, J. W. (Ed.), Field methods in cross-cultural research (ss. 137-164). Beverly Hills, CA: Sage.

Byrne, B. M. (2010). Structural equation modeling with AMOS: basic concepts, applications, and programming (2nd edition). New York.: Routledge.

Cohen, R. J., \& Swerdlik, M. E. (2018). Psychological testing and assessment: an introduction to tests and measurement (9th edition). The McGraw-Hill Companies. https://doi.org/10.1007/978-1-4899-0222-1_8

Cole, D. A. (1987). Utility of confirmatory factor analysis in test validation research. Journal of Consulting and Clinical Psychology, 55(4), 584-594. https://doi.org/10.1037/0022-006X.55.4.584

Comrey, A. L. (2013). A first course in factor analysis (2nd edition). New York: Psychology Press.

Cook, D. A., \& Beckman, T. J. (2006). Current concepts in validity and reliability for psychometric instruments: theory and application. American Journal of Medicine, 119(2), 166.e7-166.e16. https://doi.org/10.1016/j.amjmed.2005.10.036 
Danayiyen, A., \& Bekaroglu, S. B. (2019). Hastanelerde yüksek performansli iş sistemleri ölçeğinin geçerlilik ve güvenirlik (pilot) çalışması. In 3. International 21. National Public Health Congress.

Davis, L. L. (1992). Instrument review: getting the most from a panel of experts. Applied Nursing Research, 5(4), $194-197$. https://doi.org/10.1016/S0897-1897(05)80008-4

Delery, J. E., \& Doty, D. (1996). Modes of theorizing in strategic human resource management: test of universalistic, contingency and configurational performance predictions. Academy of Management Journal, 39(4), 802-835. https://doi.org/10.2307/256713

Erkuş, A. (2019). Psikolojide ölçme ve ölçek geliştirme-I: Temel kavramlar ve işlemler. Ankara: Pegem Akademi Yayıncılık.

Etchegaray, J. M., St. John, C., \& Thomas, E. J. (2011). Measures and measurement of high-performance work systems in health care settings: propositions for improvement. Health Care Management Review, 36(1), 38-46. https://doi.org/10.1097/HMR.0b013e3181f685a4

Etchegaray, J. M., \& Thomas, E. J. (2015). Engaging employees: the importance of high-performance work systems for patient safety. Journal of Patient Safety, 11(4), 221-227. https://doi.org/10.1097/PTS.0000000000000076

Garman, A. N., McAlearney, A. S., Harrison, M. I., Song, P. H., \& McHugh, M. (2011). High-performance work systems in health care management, part 1: development of an evidence-informed model. Health Care Management Review, 36(3), 201-213. https://doi.org/10.1097/HMR.0b013e318201d1bf

Gkorezis, P., Georgiou, L., \& Theodorou, M. (2018). High-performance work practices and nurses' intention to leave: the mediating role of organizational cynicism and the moderating role of human resource management-related educational background. International Journal of Human Resource Management, 29(3). 465-484. https://doi.org/10.1080/09585192.2016.1255906

Gürsakal, N. (2001). Sosyal bilimlerde araştırma yöntemleri. Bursa: Uludağ Üni. Güçlendirme Vakfı.

Harley, B., Allen, B. C., \& Sargent, L. D. (2007). High performance work systems and employee experience of work in the service sector: the case of aged care. British Journal of Industrial Relations, 45(3), 607-633. https://doi.org/10.1111/j.1467-8543.2007.00630.x

Hong, Y., Jiang, Y., Liao, H., \& Sturman, M. C. (2017). High performance work systems for service quality: boundary conditions and influence processes. Human Resource Management, 56(5), 747-767. https://doi.org/10.1002/hrm.21801

Huselid, M. A. (1995). The impact of human resource management practices on turnover, productivity, and corporate financial performance. Academy of Management Journal, 38(3), 635-672. https://doi.org/10.5465/256741

Jöreskog, K. G., \& Sörbom, D. (1984). LISREL-VI user's guide. Scientific Software.

Karagöz, Y. (2019). SPSS-AMOS-META uygulamalı istatistiksel analiz. Ankara: Atlas Akademik Basın Yayım Dağ. Ltd.Şti.

Kellner, A., Townsend, K., \& Wilkinson, A. (2017). The mission or the margin? A high-performance work system in a non-profit organisation. International Journal of Human Resource Management, 28(14), 1938-1959. https://doi.org/10.1080/09585192.2015.1129636

Kloutsiniotis, P. V., \& Mihail, D. M. (2017). Linking innovative human resource practices, employee attitudes and intention to leave in healthcare services. Employee Relations, 39(1), 34-53. https://doi.org/10.1108/ER-11-2015-0205

Laschinger, H. K. S., Finegan, J. E., Shamian, J., \& Wilk, P. (2004). A longitudinal analysis of the impact of workplace empowerment on work satisfaction. Journal of Organizational Behavior: The International Journal of Industrial, Occupational and Organizational Psychology and Behavior, 25(4), 527-545. https://doi.org/10.1002/job.256

Lengnick-Hall, M. L., Lengnick-Hall, C. A., Andrade, L. S., \& Drake, B. (2009). Strategic human resource management: the evolution of the field. Human Resource Management Review, 19(2), 64-85. https://doi.org/10.1016/j.hrmr.2009.01.002

Mayer, R. C., \& Davis, J. H. (1999). The effect of the performance appraisal system on trust for management: a field quasi-experiment. Journal of Applied Psychology, 84(1), 123-136. https://doi.org/10.1037/0021-9010.84.1.123

McAlearney, A. S., Garman, A. N., Song, P. H., McHugh, M., Robbins, J., \& Harrison, M. I. (2011). High-performance work systems in health care management, part 2: Qualitative evidence from five case studies. Health Care Management Review, 36(3), 214-226. https://doi.org/10.1097/HMR.0b013e3182100dc4

McAlearney, A. S., Hefner, J., Robbins, J., \& Garman, A. N. (2016). Toward a high-performance management system in health care, part 4. Health Care Management Review, 41(3), 233-243. https://doi.org/10.1097/HMR.0000000000000067 
Mielke, J., De Geest, S., Beckmann, S., Leppla, L., Luta, X., Guerbaai, R. A., \& Schwendimann, R. (2019). The German version of the high-performance work systems questionnaire (HPWS-G) in the context of patient safety: a validation study in a Swiss university hospital. BMC Health Services Research, 19(1), 356. https://doi.org/10.1186/s12913-019-4189-8

Mihail, D. M., \& V. Kloutsiniotis, P. (2016). Modeling patient care quality: an empirical high-performance work system approach. Personnel Review, 45(6), 1176-1199. https://doi.org/10.1108/PR-03-2015-0068

Özçelik, G., Aybas, M., \& Uyargil, C. (2016). High performance work systems and organizational values: resource-based view considerations. Procedia - Social and Behavioral Sciences, 235(October), 332-341. https://doi.org/10.1016/j.sbspro.2016.11.040

Parasuraman, A., Zeithaml, V. A., \& Berry, L. L. (1988). SERVQUAL: a multiple-item scale for measuring consumer perception of services quality. Journal of Retailing, 64(1), 12-40.

Pfeffer, J. (1995). Producing sustainable competitive advantage through the effective management of people. Academy of Management Perspectives, 9(1), 55-69. https://doi.org/10.5465/ame.2005.19417910

Posthuma, R. A., Campion, M. C., Masimova, M., \& Campion, M. A. (2013). A high-performance work practices taxonomy: integrating the literature and directing future research. Journal of Management, 39(5), 1184-1220. https://doi.org/10.1177/0149206313478184

Robbins, J., \& McAlearney, A. S. (2018). Toward a high-performance management system in health care, part 5. Health Care Management Review, 45(4), 1. https://doi.org/10.1097/hmr.0000000000000228

Ross, S. C., \& Koys, D. J. (2011). High-Involvement management: participative strategies for improving organizational performance. Academy of Management Review, 12(3), 567-570. https://doi.org/10.5465/amr.1987.4306574

Şencan, H. (2005). Sosyal ve davranışsal ölçümlerde güvenilirlik ve geçerlilik. Ankara: Seçkin Yayıncılık.

Slavec, A., \& Drnovsek, M. (2013). Affectivity, openness, and self-efficacy: linking entrepreneur's personality to innovation. Academy of Management Proceedings, 2013(1), 13750). Briarcliff Manor, NY 10510: Academy of Management.

Spence Laschinger, H. K., Finegan, J., Shamian, J., \& Wilk, P. (2001). Impact of structural and psychological empowerment on job strain in nursing work settings. Journal of Nursing Administration, 31(5), 260-272. https://doi.org/10.1097/00005110-200105000-00006

Spreitzer, G. M. (1995). Psychological empowerment in the workplace: dimensions, measurement, and validation. Academy of Management Journal, 38(5), 1442-1465. https://doi.org/10.5465/256865

Sürgevil, O., Tolay, E., \& Topoyan, M. (2013). Yapısal güçlendirme ve psikolojik güçlendirme ölçeklerinin geçerlilik ve güvenirlilik analizleri. Journal of Yasar University, 8(31), 5371-5391. https://doi.org/10.1007/s13398-014-0173-7.2

Van De Voorde, K., Paauwe, J., \& Van Veldhoven, M. (2010). Predicting business unit performance using employee surveys: monitoring HRMrelated changes. Human Resource Management Journal, 20(1), 44-63. https://doi.org/10.1111/j.1748-8583.2009.00114.x

Villajos, E., Tordera, N., \& Peiró, J. M. (2018). Refinement and validation of a comprehensive scale for measuring HR practices aimed at performance-enhancement and employee-support. European Management Journal, 37(3), 387-397. https://doi.org/10.1016/j.emj.2018.10.003

Wang, Z., Xing, L., \& Zhang, Y. (2019). Do high-performance work systems harm employees' health? An investigation of service oriented HPWS in the Chinese healthcare sector. International Journal of Human Resource Management, 1-34. https://doi.org/10.1080/09585192.2019.1579254

West, M. A., Borrill, C., Dawson, J., Scully, J., Carter, M., Anelay, S., \& Waring, J. (2002). The link between the management of employees and patient mortality in acute hospitals. The International Journal of Human Resource Management, 13(8), $1299-1310$. https://doi.org/10.1080/09585190210156521

Zacharatos, A., Barling, J., \& Iverson, R. D. (2005). High-performance work systems and occupational safety. Journal of Applied Psychology, 90(1), 77-93. https://doi.org/10.1037/0021-9010.90.1.77 